\title{
PERBANDINGAN PELAKSANAAN EUTHANASIA DI NEGARA YANG MENGANUT SISTEM HUKUM EROPA KONTINENTAL DAN SISTEM HUKUM ANGLO SAXON
}

Muh. Amiruddin

\author{
Universitas Islam Negeri (UIN) Alauddin Makassar \\ Email: Udinktabrani@yahoo.co.id
}

\begin{abstract}
The country that adheres to the continental european legal system of Indonesia that regulate euthanasia is contained in the provisions of Article 344 of the Criminal Code while Netherlands The provisions are contained in the code penal section 40 and Article 293 of the Dutch Criminal. Code anglo saxon like USA hardness of euthanasia. this is based on a court decision in USA that rejects the application of euthanasia as a jurisprudence. Indonesia does not Regulate clearly about the enactment of euthanasia. Netherlands legalize Euthanasia, while State with Anglo Saxon Law system, does not legalize Euthanasia
\end{abstract}

Keywords: Euthanasia, Continental European Legal System, Anglo Saxon Legal System

\begin{abstract}
Abstrak
Negara yang menganut sistem hukum eropa kontinental yaitu Indonesia yang mengatur tentang Euthanasia yaitu termuat dalam ketentuan pasal 344 KUHP sementara di Belanda ketentuan ini dimuat dalam code penal section 40 dan pasal 293 KUHP Belanda. Sistem hukum Anglo saxon seperti Amerika Serikat melarang keras adanya euthanasia. hal ini didasarkan adanya putusan pengadilan di Amerika Serikat yang menolak penerapan euthanasia sebagai sebuah yurisprudensi. Indonesia tidak Mengatur secara jelas tentang pemberlakuan euthanasia. Belanda melegalkan Euthanasia, sedangkan negara dengan sistem Hukum Anglo Saxon tidak melegalkan Euthanasia

Kata Kunci: Euthanasia, Sistem Hukum Eropa Kontinental, Sistem Hukum Anglo Saxon
\end{abstract}




\section{PENDAHULUAN}

istem hukum adalah suatu kesatuan yang memiliki unsur-unsur yang mempunyai interaksi satu sama lain dan bekerjasama untuk mencapai tujuan kesatuan tersebut. Didunia ini sistem hukum tidak dapat dipisahkan dari kehidupan kita sehar-hari. Ada banyak sistem hukum di dunia ini. dua diantaranya adalah sistem hukum eropa kontinental dan sistem hukum anglo saxon. Sistem hukum eropa kontinental adalah suatu sistem hukum dengan ciriciri adanya berbagai ketentuan-ketentuan hukum dikodifikasi atau dihimpun secara sistematis yang akan ditafsirkan lebih lanjut oleh hakim dalam penerapannya.

Dalam perkembangannya, prinsip-prinsip hukum yang terdapat pada sistem hukum ini dijadikan dasar perumusan dan kodifikasi di negara-negara Eropa daratan seperti Belanda dan Indonesia yang memiliki prinsip utama dimana hukum memperoleh kekuatan mengikat karena diwujudkan dalam peraturan perundang-undangan dan tersusun secara sistematik dalam kodifikasi atau kompilasi tertentu.

Nilai utama yang dianut yang merupakan tujuan hukum adalah kepastian hukum, kepastian hukum ini dapat diwujudkan jika tindakan-tindakan hukum manusia didalam pergaulan hidup diatur dengan peraturan-peraturan yang tertulis yang sumber hukumnya terdapat dalam undang-undang yang dibentuk oleh pemegang kekuasaan legislatif, selain itu diakui juga peraturan-peraturan yang dibuat oleh pemegang kekuasaan eksekutif berdasarkan wewenang-wewenang yang telah ditetapkan oleh undang-undang (peraturan-peraturan hukum administrasi) negara dan kebiasaan-kebiasaan yang hidup dan diterima sebagai hukum oleh masyarakat selama tidak bertentangan dengan undang-undang.

Sistem hukum lainnya adalah anglo saxon yaitu sistem hukum yang dianut oleh beberapa negara yang diantaranya negara Amerika Serikat dan Inggris. Sistem hukum ini adalah suatu sistem hukum yang didasarkan pada yurisprudensi yaitu keputusan-keputusan hakim terdahulu yang kemudian menjadi dasar putusan hakim-hakim selanjutnya.

Disamping putusan hakim maka kebiasaan-kebiasaan dan peraturanperaturan tertulis undang-undang dan peraturan administrasi negara walaupun banyak landasan yang terbentuk dalam sebuah kebiasaan dan peraturan tertulis itu berasal dari putusan-putusan didalam pengadilan. Sumber-sumber hukum tersebut (putusan hakim, kebiasaan, dan peraturan administrasi negara) tidak tersusun secara hierarki seperti pada sistem hukum eropa kontinental. 
Aturan hukum mengenai masalah ini berbeda-beda disetiap negara dan seringkali berubah seiring dengan adanya perubahan norma-norma budaya maupun ketersediaan perawatan atau tindakan medis. Di beberapa negara, euthanasia dianggap legal, sedangkan dinegara lain dianggap melanggar hukum. Oleh karena itu sensitifnya isu ini pembatasan dan prosedur yang ketat selalu diterapkan tanpa memandang status hukumnya.

Pihak yang menyetujui euthanasia dapat dilakukan, hal ini berdasarkan bahwa setiap manusia memiliki hak untuk hidup dan hak untuk mengakhiri hidupnya dengan segera dan hal ini dilakukan dengan alasan yang cukup mendukung yaitu alasan kemanusian. Dengan keadaan dirinya yang tidak lagi memungkinkan untuk sembuh atau bahkan hidup, maka ia dapat melakukan permohonan untuk segera diakhiri hidupnya. Sementara sebagian pihak yang tidak membolehkan euthanasia beralasan bahwa setiap manusia tidak memiliki hak untuk mengakhiri hidupnya, karena masalah hidup dan mati adalah kekuasaan mutlak Tuhan yang tidak bisa diganggu gugat oleh manusia.

Perdebatan ini tidak akan pernah berakhir, karena sudut pandang yang dipakai sangatlah bertolak belakang, dan lagi-lagi alasan perdebatan tersebut adalah masalah legalitas dari perbuatan euthanasia.

\section{PEMBAHASAN}

A. Aturan Norma Hukum tentang Euthanasia di Negara Eropa Kontinental dan Anglo Saxon

1. Aturan Norma Hukum tentang Euthanasia di Negara Eropa Kontinental (Indonesia-Belanda)

Pada negara eropa kontinental seperti Indonesia pengaturan tentang euthanasia tidak diatur dengan jelas dalam Undang-undang Nomor 39 Tahun 1999 tentang Hak Azasi Manusia (UU HAM). Pada pasal 9 ayat (1) UU HAM berbunyi bahwa setiap orang berhak untuk hidup dan meningkatkan taraf hidupnya. Hak untuk hidup oleh sebagian besar masyarakat dapat ditafsirkan sebagai hak untuk menentukan hidupnya sendiri. Akan tetapi, hak untuk menentukan hidupnya sendiri tidak dapat berdiri sendiri tanpa adanya suatu hak atas informasi yang diatur dalam Pasal 14 UU HAM dan hak atas kesehatan yang diatur dalam pasal 9 ayat (3) UU HAM. Berlandaskan pada ketentuan tersebut pasien dan keluarga yang mewakili setelah mendapatkan informasi yang jelas dapat meminta persetujuan dari dokter untuk meminta dihentikannya pengobatan karena pasien dianggap tidak dapat disembuhkan lagi, sehingga keberadaanya di rumah sakit 
hanya dapat menambah beban serta biaya. Persetujuan antara dokter dan pasien inilah yang dapat menjadi dasar untuk dilakukannya euthanasia terhadap pasien, Dengan demikian, dokter tidak dapat dipersalahkan apabila pihak keluarga mengadukannya karena tindakannya dilakukan atas persetujuan pasien dan keluarga pasien yang biasa dikenal dengan istilah Informa consent yaitu syarat yang bertumpuh antara dua hak yaitu hak untuk menentukan hidupnya sendiri dan hak untuk mendapatkan informasi.

Ketentuan tentang eutahanasia tidak diatur secara jelas dalalam peraturan perundang-undangan Indonesia. Secara eksplisit euthanasia diatur dalam UU HAM yaitu hak hidup yang ditafsirkan oleh sebagian masyarakat merupakan hak untuk menentukan hidupnya sendiri. Bentuk Euthanasia yang sering dilakukan di Indonesia adalah bentuk euthanasia pasif yaitu bentuk pengurangan kesehatan. Bentuk euthanasia pasif dalam ketentuan perundang-undangan di Indonesia memang belum diatur secara jelas, sehingga pelaksanaanya bukan merupakan sebuah pelanggaran hukum.

Pasal 344 KUHP yang oleh para ahli hukum merupakan pasal yang mendekati tindakan euthanasia termasuk juga euthanasia pasif tidak dapat bekerja secara maksimal karena belum ada menjerat pelaku euthanasia pasif di Indonesia. Sedangkan di Belanda Yang pertama kali melegalkan euthanasia hanya dapat dilakukan jika si pasien sendiri meminta dan telah memenuhi syarat untuk dilakukannya tindakan euthanasia.

\section{Aturan Norma Hukum tentang Euthanasia di Negara Anglo Saxon}

Negara penganut sistem hukum anglo saxon seperti Amerika Serikat secara tegas melarang pemberlakuan euthanasia baik pasif maupun aktif, euthanasia sangat di larang tegas di Amerika Serikay karena merupakan perbuatan melanggar hukum. Akan tetapi, di salah satu negara bagian di Amerika yaitu Oeregeon hal yang legal, ketentuan ini berdasarkan pada, Oregeon death with dignity act, bahwa disebutkan, seorang pasien yang tidak dapat disembuhkan lagi dapat mengakhiri hidupnya, Masalah hak untuk mati ini di beberapa negara maju, sudah ada pengaturannya di dalam perundang-undangan di negara tersebut, seperti negara Eropa, tetapi hak untuk mati itu tidak bersifat mutlak, seperti adanya putusan pengadilan Negeri Leeuwarden dari Pengadilan Negeri menetapkan tolak ukur perumusan " tidak dikenal hukum" atau tanpa hukuman, terhadap euthanasia yang dilakukan. 
Pelaksanaan Euthanasia, di negara bagian Amerika Oregionpun pelaksanaan euthanasia sangat diperketat, dengan syarat-syarat tertentu antara lain:

a. Orang yang ingin diakhiri hidunya adalah orang yang benar-benar sakit dan tidak dapat diobati misalnya Kanker.

b. Pasien berada dalam keadaan dimana kemungkinan hidupnya kecil dan hanya menunggu waktu kematian.

c. Pasien harus menderita sakit yang amat sangat, sehingga penderitaanya hanya dapat dikurangi dengan pemberian morfin,

d. Pihak yang berhak melakukan pengakhiran hidup pasien, hanyalah dokter keluarga yang merawat pasien dan ada dasar penilaian dari dua orang dokter spesialis yang menentukan dapat tidaknya dilakukan euthanasia.

Semua persyaratan tersebut harus dapat dipenuhi baru euthanasia dapat dilaksanakan.

\section{B. Pelaksanaan Euthanasia di Negara yang menganut sistem hukum Eropa continental}

\section{Di Belanda}

Pada tanggal 10 April 2001 Belanda Menerbitkan Undang-undang yang mengizinkan euthanasia yaitu wet van 12 April 2001,

hondende toetsing van levensbeendiging op verzek en hulp bij lijkberzorging atau Review prosedures for the termination of life on reguest and assisted suicide and amandement of the Criminal code and the Burial and Crimation Act. ${ }^{1}$

Undang-undang ini dinyatakan efektif berlaku sejak tanggal 1 april 2002, yang menjadikan Belanda negara pertama di Dunia yang melegalisasikan Praktek Euthanasia. Pasien-pasien yang mengalami sakit menahun dan tak tersembuhkan, diberi hak untuk mengakhiri penderitaannya. Tetapi perlu di tekankan, bahwa

1 Lihat (http://www international task force.org/rpt 2005-3 htm \# 238 diakses tanggal 2 Januari 2017) 
dalam kitab Undang-undang Hukum Pidana Belanda secara formal euthanasia dan bunuh diri berbantuan masih dipertahankan dan dianggap kriminal. ${ }^{2}$

Di Belanda, keluarga boleh mengajukan euthanasia jika kondisi pasien sudah parah dan sangat menderita dengan penyakitnya. Selain itu, pasien dengan umur lebih dari 12 tahun bisa mengajukan pendampingan bunuh diri. Yang dimaksud pendampingan bunuh diri adalah pasien dengan sadar meminta disuntik mati karena keadaannya yang parah. Akan tetapi perlu ditekankan, bahwa dalam Kitab Hukum pidana Belanda secara formal euthanasia dan bunuh diri berbantuan masih dipertahankan sebagai perbuatan kriminal, Setiap dokter di Belanda di- mungkinkan melakukan euthanasia dan tidak akan dituntut di depan pengadilan asalkan mengikuti beberapa prosedur yang telah ditetapkan. Prosedur tersebut adalah mengadakan konsultasi dengan rekan sejawat (tidak harus seorang dokter spesialis) dan membuat laporan dengan menjawab 50 pertanyaan.

Persetujuan Parlemen Belanda atas usulan legalisasi kegiatan dokterdokter Belanda untuk membantu pasien-pasien penderita penyakit parah yang memilih untuk mengakhiri hidupnya ini diperoleh setelah dilakukan pemungutan suara (voting). Dukungan 104 suara berbanding 40 suara yang menolak telah membuktikan keberpihakan parlemen untuk segera memberlakukan UU legalisasi euthanasia.

Euthanasia mendapat dukungan publik besar-besaran di Belanda tetapi ada kekhawatiran bahwa praktek ini mengarah pada penyalahgunaan hukum, Euthanasia tidak menjadi tindak pidana di Belanda, sejak tahun 1984 ketika pengadilan the Royal medical asosioation menyusun pedoman yang ketat untuk Dokter. Perubahan Undang-Undang yang baru, akan menghapus setiap kemungkinan Bahwa dokter akan dituntut untuk melakukan euthanasia dengan peretujuan dan konsultasi.

Studi British Medical Journal menemukan bahwa pada tahun 1995, hampir dua pertiga dari kasus euthanasia a bunuh diri yang dibantu dokter tidak dilaporkan. $17 \%$ dari kasus-kasus euthanasia terjadi tanpa permintaan eksplisit pasien. Hukum Belanda mengharuskan penderitaan tak tertahankan oleh pasien untuk membenarkan dilakukannnya euthanasia, Tapi lebih dari setengah dokter mengatakan bahwa alasan utama yang diberikan oleh pasien untuk permintaan ini adalah kehilangan martabat, Hampir setengahnya mengatakan mereka mencegah penderitaan lebih lanjut.

2 Wellywahyura, http//welywahyura, wordpress.com. Euthnaasia/ Diakses tanggal 2 Januari 2017) 
Sebuah Karangan berjudul " The slippery Slop Of Dutch Euthanasia" dalam majalah Human life Internasional, spesial Report Nomor 67, November 1998, halaman tiga melaporkan bahwa sejak tahun 1994 setiap dokter di Belanda dimungkinkan melakukan euthanasia dan tidak akan dituntut di pengadilan asalkan mengikuti beberapa prosedur yang ada. Prosedur tersebut adalah melakukan konsultasi dengan teman sejawat sekitar 50 pertanyaan. ${ }^{3}$

Sejak akhir tahun 1993, Belanda secara hukum mengatur kewajiban para dokter untuk melapor semua kasus euthanasia dan bunuh diri berbantuan, Instansi kehakiman selalu akan menilai betul betul tidaknya prosedur yang diterapkan, Pada tahun 2002 Sebuah konvensi yang berusia 20 Tahun telah dikodifikasi oleh Undang-undang Belanda dimana seorang dokter yang melakukan euthanasia pada suatu kasus tertentu tidak akan dihukum, Dinyatakan bahwa bunuh diri berbantuan dilakukan atas dasar penderitaan berkelanjutan dan tak tertahankan lagi, adalah Legal. Dan selanjutnya dalam aturan tersebut mentebutkan bahwa pasien harus dalam keadaan tenang. Dokter pun harus mendapatkan opini ke duadan hanya dokter bukan keluarga yang hak memberika obat mematikan pada pasien.

Menurut penelitian pada tahun 1999, otoritatif dalam laporan remmelink mendifinisikan euthanasia di Belanda, sebagai sengaja mengakhiri hidup, orang lain atas permintaannya. Ini berbeda dari kategori lainnya yang digunakan di lembaga-lembaga perawatan kesehatan Belanda yaitu:

Bantuan bunuh diri yang didefinisikan sebagai sengaja membantu seseorang dalam tindakan mengakhiri hidupnya yang merupakan permintaan eksplisit, hal ini berbeda dengan permintaan euthanasia sukarela karena tidak mendukung tujuan hanya dalam tindakan penghancuran diri yaitu:

a. Sebuah tindakan mengakhiri hidup tanpa pemintaan ekplesit di definisikan sebagai usaha mengahiri hidup seseorang tanpa ada permintaan eksplisit. Hal ini berbeda dengan euthanasia sukarela dalam hal ini tidak didasarkan pada permintaan yang dianggap baik., gigih dan eksplesit dari pasien.

3 Anonim, Aspek Hukum Dalam Pelaksanaan Euthanasia Di Indonesia (http://hukumkes.wordpress.com/2008/03/15/aspek-hukum-dalam-pela ksanaan-euthanasia-diindonesia/), diakses pada hari Senin, 02 Juli 2012, Pukul 18:10 WITA. 
b. Euthanasia aktif tanpa permintaan eksplisit dari pasien berbeda dari euthanasia sukarela karena tidak didasarkan pada permintaan yang dianggap baik, gigih dan eksplisit dari pasien.

c. Kematian akibat administrasi obat penghilang rasa sakit lainnya dalam dosis besar .ini dikenal sebagai euthanasia tidak langsung.

Dalam definisi ini, definisi resmi pengakhiran hidup atas permintaan pasien adalah pusat dari keputusan untuk mengakiri dalam kasus euthanasia sukarela, Definisi diatas serupa dengan yang digunakan secara internasional dalam biotika. $^{4}$

Pada tanggal 10 april 2001. Sebelum tanggal tersebut euthanasia aktif adalah tindak pidana berdasarkan article 293 of dutch penal code (pasal 293 dari Belanda KUHP) yang berbunyi :

"hi hu takes the life of another person on this person expicit and serious request will be punished with imprisonment of up twelve years or a fine of the fifth category. "

(dia yang mengambil kehidupan orang lain atas permintaan orang ini eksplisit dan serius akan dihukum dengan hukuman penjara hingga 12 tahun atau denda kategori ke-5 (sekitar USD 50).

Kemudian dalam artikel 294 the dutch penal code pasal 294 KUHP Belanda berbunyi :

"he who deliberately incites another to sucide, assist him therein orprovides him with the means, is punished, if the suicide follows, with a sentence of at most three years or a fine of the fourth category" ( Dia yang sengaja menghasut orang lain untuk buh diri, membantu dalamnya atau memberikan dia dengan sarana, dihukum dengan hukuman yang paling banyak 3 tahun atau denda dengan kategori 4 . Sekitar 12,500 USD

Pada saat yang sama, section 40 (bagian 40) dari code penal yang sama menyatakan bahwa seorang individu tidak dihukum jika ia telah didorong oleh suatu kekuatan yang tak tertahankan. Hukum dikenal sebagai (force majure) untuk menempatkan kesejahteraan orang lain diatas hukum ini mungkin termasuk

4 Robbin Lauge, Maria Royle, Michel Slater. http;// www.leg state.vt.us/report/05 death/death with/_dignityreport htm diakses 24 januari 2017.

${ }^{5}$ www.lecsadin .nl/wlg/legis/iur/nor/wnet.htm\#kriminal\%20.law. diakses pada tanggal 2 januari 2017 
keadaan dimana dokter dihadapkan dengan konflik antara kewajiban hukum untuk tidak mengambil kehidupan dan tugas manusiawi untuk mengakhiri penderitaan tak tertahankan pasien.

Di Belanda euthanasia sukarela telah diilegalkan. Dekriminalisasi euthanasia membuat Belanda negara pertama di dunia yang secara resmi "belas kasihan membunuh". Dalam UU euthanasia syarat-syarat yang dilakukan euthanasia adalah, ${ }^{6}$

a. pasien yang dalam kedaan menderita terus menerus, tak tertahankan dan tidak dapat disembuhkan;

b. sebuah pendapat kedua seorang dokter eksternal;

c. pasien harus sehat jasmani;

d. permintaan untuk mati harus dilakukan secara sukarela, independen dan terus menerus;

e. pasien harus sakit parah dengan penderitaan fisik; dan

f. pasien yang berumur 12 tahun memerlukan persetujuan dari orang tua mereka $^{7}$

Dokter tidak seharusnya menyarankan sebagai pilihan, kedua permintaan lisan dan tertulis melegitimasi dokter untuk menyetujui permintaan tersebut. Namun, dokter tidak diwajibkan untuk melakukannya. dan Dokter hanya dapat menyetujui untuk meminta sambil memperhatikan perawatan karena persyaratan yang disebutkan dalam Undang-undang. Dalam setiap kasus dokter harus yakin bahwa pasien dalam menghadapi penderitaan berkesudahan dan tak tertahankan. Jika dia percaya bahwa ini tidak seperti itu adanya dokter mungkin menyetujui permintaan euthanasia tidak peduli dilegalkan atau tidak dilegalkan oleh negara.

Penting untuk dicatat bahwa euthanasia dan bunuh diri yang dibantu dokter terus menjadi tindak pidana, tetapi dilegalkan dalam keadaan tertentu. KUHP Belanda (dalam pasal 293) sekarang termasuk dalam ketentuan itu hal ini menyatakan bahwa berakhirnya kehidupan oleh sebuah permintaan bantuan bunuh diri tidak diperlukan sebagai tindak pidana bila dilakukan oleh dokter dan jika kriteria perawatan yang sesuai prosedur. oleh karena itu pandangan bahwa

\footnotetext{
${ }^{6}$ Undang - Undang No.29 tahun 2004 tentang praktik kedokteran

${ }^{7}$ www.lecsadin .nl/wlg/legis/iur/nor/wnet.htm\#kriminal\%20.law. diakses pada tanggal 2
} januari 2017 
euthanasia dilegalkan dan tidak termasuk pidana dalam ketentuan hukum di Belanda.

Dalam contoh kasus yang menimpa seorang pasien yang bernama nyonya Netti mengalami depresi karena kegagalan perkawinan dan dua anaknya meninggal karena bunuh diri dan kanker. Penderitaannya terutama psikologis. Setelah kematian anak ke dua ia memutuskan untuk bunuh diri dan mendekati federasi Belanda sukarela euthanasia yang mengarah ke dokter nama dokter tersebut adalah Bowdewijen chabot. Dokter tersebut mendiagnosa menderita penyakit mental yang berat dan sulit dipecahkan. Dia berkonsultasi dengan sejumlah rekan-rekannya, meski tidak satupun dari mereka yang memeriksa nyonya netti secara pribadi. Pada bulan september tahun 1991. Dokter Bowdewijen melakukan euthanasi pada Nyonya Netti dengan resep obat dosis tinggi yang mematikan akibat dia dilaporkan kekoroner publik.

Dokter tersebut dituntut berdasarkan pada pasal 294 dari KUHP Belanda. Mahkamah Agung menyatakan bahwa tidak ada alasan prinsip dilakukan euthanasia apabila penyebab penderitaan pasien adalah psikologis. Namun, pengadilan menyatakan bahwa untuk melakukan euthanasia pasien harus diperiksa oleh ahli medis independen. Dokter Bwijen telah mencari pendapat medis dari 7 orang temannya tetapi tidak ada yang benar-benar melihat bahwa nyonya Netti dapat disembuhkan. Pada bulan juni 1994, dr. Bowjene ditetapkan bersalah karena melakukan kejahatan berdasarkan pasal 294. Mahkamah Agung menolak untuk menjatuhkan hukuman, walaupun pada bulan februari 1995 dr.Bowjene menerima teguran dari majelis disiplin kedokteran. ${ }^{8}$

Sejak akhir tahun 1993, Belanda secara hukum mengatur kewajiban para dokter untuk melaporkan semua kasus bunuh diri berbantuan. Instansi kehakiman akan selalu akan menilai betul tidaknya prosedurnya. Pada tahun 2002, sebuah konvensi yang berusia 20 tahun telah dikodifikasi oleh undang-undang Belanda, dimana seorang Dokter yang melakukan euthanasia pada suatu kasus tertentu tidak akan dihukum.

Dengan UU yang mulai diberlakukan tahun depan ini, Belanda menjadi negara pertama yang melegalkan euthanasia. Praktek ini sendiri sudah sering dilakukan di seluruh dunia, meskipun secara teknis masih menjadi tindakan kriminal. Lower house parlemen Belanda menyetujui keputusan ini, di mana dukungan dari senat sudah pasti diberikan.

${ }^{8}$ Kimsma G, Leeuwen. www.eubios.info/BetCD/Bet12.doc diakses 2 januari 2017. 
Keputusan Parlemen Belanda itu langsung dihujat oleh Vatikan. "Adalah sesuatu yang sangat menyedihkan bagi orang-orang Belanda untuk menjadi negara pertama yang justru menginginkan pemberlakuan euthanasia yang mencoreng harga diri manusia," protes juru bicara Vatican, Joaquin NavarroValls. UU yang melegalkan euthanagsia ini, menurut Vatikan, akan memberikan pertanyaan-pertanyaan moral yang amat serius yang harus dihadapi dokter-dokter Belanda.

Sekeras apapun kecaman Vatikan itu telah teropinikan bahwa masyarakat Belanda dan kalangan medisnya memberikan restu untuk memuluskan diterbitkannya Undang-undang legalisasi tersebut. Menurut mereka, euthanasia sebetulnya bertujuan untuk menjelaskan dan mengklarifikasikan suatu praktek yang telah dilakukan secara luas oleh dokter-dokter Belanda.

Undang-Undang baru yang diajukan oleh Menteri Kehakiman dan Menteri Kesehatan ini, seperti diberitakan New York Times, hanya berlaku bagi para dokter, dan bukan bagi orang-orang di luar profesi medis yang membantu dalam situasi pasien yang ingin bunuh diri. Undang-Undang euthanasia ini mengandung aturan-aturan yang ditulis oleh Royal Dutch Medical Association. Aturan-aturan itu mengatur bahwa permintaan pasien untuk bunuh diri harus datang dari dirinya sendiri dan diajukan berkali-kali.

Sementara dokter yang berhubungan dengan pasien itu harus merasa yakin bahwa si pasien memang sedang menghadapi penderitaan yang tak tertahankan dan tidak bisa dihentikan. Sang dokter tidak boleh mengajukan upaya bunuh diri sebagai salah satu pilihan. Dokter-dokter ini harus terlebih dahulu mencari opini medis kedua (second medical opinion) sebelum membantu seorang pasien untuk bunuh diri. Dokter-dokter itu pun harus menyatakan bahwa sebab kematian si pasien adalah euthanasia atau bunuh diri.

Dokter-dokter yang telah membantu dalam proses euthanasia itu pun akan tetap dianggap bertanggungjawab atas partisipasi mereka. Akan tetapi, karena euthanasia sudah bukan lagi tindakan kriminal, sang dokter tidak akan berhadapan dengan pengadilan. Dokter-dokter itu akan dihadapkan pada suatu panel informal, yang terdiri atas ahli hukum, ahli medis, dan ahli ethis.

Tindakan untuk mengakhiri hidup seseorang yang dilakukan di negeri Belanda adalah terlalu bebas dan malah berpotensi bahaya. hal ini diungkap oleh beberapa pakar hukum di Belanda. Negeri ini menganut "active Euthanasia" artinya secara hukum permohonan seseorang yang kompeten untuk mengakhiri 
hidupnya dapat dikabulkan. Berdasarkan Dutch Penal Codes Article 293, 294 kegiatan euthanasia atau "assisted suicide" dilindungi oleh hukum dengan beberapa panduan yang ditetapkan oleh pengadilan di Rotterdam tahun 1981 sebagai berikut:

a. Pasien harus dalam kondisi nyeri yang tidak tertahankan.

b. Pasien harus dalam keadaan sadar.

c. Permintaan mengakhiri hidup harus dilakukan secara sukarela.

d. Pasien harus diberikan alternatif selain euthanasia dan diberi waktu sebelum euthanasia dilakukan.

e. Tidak ada lagi solusi logis yang bisa dijalani.

f. Kematian pasien tidak menimbulkan penderitaan yang tidak diinginkan bagi yang lain.

g. Harus ada lebih dari satu orang yang terlibat dalam pengambilan keputusan euthanasia.

h. Hanya dokter yang dapat melakukan euthanasia terhadap pasien.

\section{Indonesia}

Di Indonesia, upaya pengajuan permohonan euthanasia ini pernah terjadi di penghujung 2004, suami Ny. Again mengajukan permohonan euthanasia ke Pengadilan Negeri Jakarta Selatan untuk mengakhiri penderitaan istrinya, namun permohonan itu ditolak oleh pengadilan. tindakan euthanasia harus memenuhi persyaratan medis dan bukan karena alasan sosial ekonomi. sifat limitatif ini untuk mencegah agar nantinya pengajuan euthanasia tidak sewenang-wenang.

Jadi, euthanasia memang dilarang di Indonesia, terutama untuk euthanasia aktif dapat dipidana paling lama 12 (dua belas) tahun penjara. Akan tetapi, dalam praktiknya tidak mudah menjerat pelaku euthanasia pasif yang banyak terjadi. Membunuh bisa dilakukan secara legal. Itulah euthanasia, pembuhuhan legal yang sampai kini masih jadi kontroversi. Pembunuhan legal ini pun ada beragam jenisnya. Secara umum, kematian adalah suatu topik yang sangat ditakuti oleh publik. Hal demikian tidak terjadi di dalam dunia kedokteran atau kesehatan. Dalam konteks kesehatan modern, kematian tidaklah selalu menjadi sesuatu yang datang secara tiba-tiba. Kematian dapat dilegalisir menjadi sesuatu yang definit dan dapat dipastikan tanggal kejadiannya. 
Euthanasia memungkinkan hal tersebut terjadi. Euthanasia adalah tindakan mengakhiri hidup seorang individu secara tidak menyakitkan, ketika tindakan tersebut dapat dikatakan sebagai bantuan untuk meringankan penderitaan dari individu yang akan mengakhiri hidupnya Bila ditinjau dari cara pelaksanaannya, eutanasia dapat dibagi menjadi tiga kategori, yaitu eutanasia agresif, eutanasia non agresif, dan eutanasia pasif. ${ }^{9}$

a. Eutanasia agresif, disebut juga eutanasia aktif, adalah suatu tindakan secara sengaja yang dilakukan oleh dokter atau tenaga kesehatan lainnya untuk mempersingkat atau mengakhiri hidup seorang pasien. Eutanasia agresif dapat dilakukan dengan pemberian suatu senyawa yang mematikan, baik secara oral maupun melalui suntikan. Salah satu contoh senyawa mematikan tersebut adalah tablet sianida.

b. Eutanasia non agresif, kadang juga disebut eutanasia otomatis (autoeuthanasia) digolongkan sebagai eutanasia negatif, yaitu kondisi dimana seorang pasien menolak secara tegas dan dengan sadar untuk menerima perawatan medis meskipun mengetahui bahwa penolakannya akan memperpendek atau mengakhiri hidupnya. Penolakan tersebut diajukan secara resmi dengan membuat sebuah "codicil" (pernyataan tertulis tangan). Eutanasia non agresif pada dasarnya adalah suatu praktik eutanasia pasif atas permintaan pasien yang bersangkutan.

c. Eutanasia pasif dapat juga dikategorikan sebagai tindakan eutanasia negatif yang tidak menggunakan alat-alat atau langkah-langkah aktif untuk mengakhiri kehidupan seorang pasien. Eutanasia pasif dilakukan dengan memberhentikan pemberian bantuan medis yang dapat memperpanjang hidup pasien secara sengaja. Beberapa contohnya adalah dengan tidak memberikan bantuan oksigen bagi pasien yang mengalami kesulitan dalam pernapasan, tidak memberikan antibiotika kepada penderita pneumonia berat, meniadakan tindakan operasi yang seharusnya dilakukan guna memperpanjang hidup pasien, ataupun

9 Rabdhan Purnama, Euthanasia Ditinjau Dari Aspek Hukum (http://rabdhanpur nama.blogspot.com/2012/07/euthanasia-ditinjau-dari-aspek-hukum. html), diakses pada hari Rabu, 03 April 2013, Pukul 09:10 WITA 
pemberian obat penghilang rasa sakit seperti morfin yang disadari justru akan mengakibatkan kematian. Tindakan eutanasia pasif seringkali dilakukan secara terselubung oleh kebanyakan rumah sakit.

Penyalahgunaan eutanasia pasif bisa dilakukan oleh tenaga medis maupun pihak keluarga yang menghendaki kematian seseorang, misalnya akibat keputusasaan keluarga karena ketidaksanggupan menanggung beban biaya pengobatan. Pada beberapa kasus keluarga pasien yang tidak mungkin membayar biaya pengobatan, akan ada permintaan dari pihak rumah sakit untuk membuat “pernyataan pulang paksa”. Meskipun akhirnya meninggal, pasien diharapkan meninggal secara alamiah Konsepsi Euthanasia dalam Oxford English Dictionary dirumuskan sebagai "kematian yang lembut dan nyaman, dilakukan terutama dalam kasus penyakit yang penuh penderitaan dan tak tersembuhkan". Istilah yang sangat populer untuk menyebut jenis pembunuhan ini adalah mercy killing Sementara itu menurut Kamus Kedokteran Dorland euthanasia mengandung dua pengertian.

1. Pertama, suatu kematian yang mudah atau tanpa rasa sakit.

2. Kedua, pembunuhan dengan kemurahan hati, pengakhiran kehidupan seseorang yang menderita penyakit yang tak dapat disembuhkan dan sangat menyakitkan secara hati-hati dan disengaja.

Secara konseptual dikenal tiga bentuk euthanasia, yaitu voluntary euthanasia (euthanasia yang dilakukan atas permintaan pasien itu sendiri) karena penyakitnya tidak dapat disembuhkan dan dia tidak sanggup menahan rasa sakit yang diakibatkannya); non voluntary euthanasia (di sini orang lain, bukan pasien, mengandaikan, bahwa euthanasia adalah pilihan yang akan diambil oleh pasien yang berada dalam keadaan tidak sadar tersebut jika si pasien dapat menyatakan permintaannya); involuntary euthanasia (merupakan pengakhiran kehidupan pada pasien tanpa persetujuannya). Konstruksi Yuridis Euthanasia Munculnya pro dan kontra seputar persoalan euthanasia menjadi beban tersendiri bagi komunitas hukum. Sebab, pada persoalan "legalitas" inilah persoalan euthanasia akan bermuara. Kejelasan tentang sejauh mana hukum (pidana) positif memberikan regulasi/pengaturan terhadap persoalan euthanasia akan sangat membantu masyarakat di dalam menyikapi persoalan tersebut. Lebih-lebih di tengah kebingungan kultural karena munculnya pro dan kontra tentang legalitasnya.

Patut menjadi catatan, bahwa secara yuridis formal dalam hukum pidana positif di Indonesia hanya dikenal satu bentuk euthanasia, yaitu euthanasia yang dilakukan atas permintaan pasien/korban itu sendiri (voluntary euthanasia) 
sebagaimana secara eksplisit diatur dalam Pasal 344 KUHP. Pasal 344 KUHP secara tegas menyatakan : "Barang siapa merampas nyawa orang lain atas permintaan orang itu sendiri yang jelas dinyatakan dengan kesungguhan hati diancam dengan pidana penjara paling lama dua belas tahun".

Bertolak dari ketentuan Pasal 344 KUHP tersebut tersimpul, bahwa pembunuhan atas permintaan korban sekalipun tetap diancam pidana bagi pelakunya. Dengan demikian, dalam konteks hukum positif di Indonesia euthanasia tetap dianggap sebagai perbuatan yang dilarang. Dengan demikian dalam konteks hukum positif di Indonesia, tidak dimungkinkan dilakukan "pengakhiran hidup seseorang" sekalipun atas permintaan orang itu sendiri. Perbuatan tersebut tetap dikualifikasi sebagai tindak pidana, yaitu sebagai perbuatan yang diancam dengan pidana bagi siapa yang melanggar larangan tersebut.

Mengacu pada ketentuan tersebut di atas, maka munculnya kasus permintaan tindakan medis untuk mengakhiri kehidupan yang muncul akhir-akhir ini (kasus Hasan Kesuma yang mengajukan suntik mati untuk istrinya, Ny. Agian dan terakhir kasus Rudi Hartono yang mengajukan hal yang sama untuk istrinya, Siti Zuleha) perlu dicermati secara hukum. Kedua kasus ini secara konseptual dikualifikasi sebagai non voluntary euthanasia, tetapi secara yuridis formal (dalam KUHP) kasus ini tidak bisa dikualifikasi sebagai euthanasia sebagaimana diatur dalam Pasal 344 KUHP.

Secara yuridis formal kualifikasi (yang paling mungkin) untuk kedua kasus ini adalah pembunuhan biasa sebagaimana dimaksud dalam Pasal 338 KUHP, atau pembunuhan berencana sebagaimana dimaksud dalam Pasal 340 KUHP. Dalam ketentuan Pasal 338 KUHP secara tegas dinyatakan, " Barang siapa sengaja merampas nyawa orang lain diancam, karena pembunuhan dengan pidana penjara paling lama lima belas tahun". Sementara dalam ketentuan Pasal 340 KUHP dinyatakan: " Barang siapa dengan sengaja dan dengan rencana lebih dulu merampas nyawa orang lain diancam, karena pembunuhan berencana, dengan pidana mati atau pidana penjara seumur hidup atau selama waktu tertentu paling lama dua puluh tahun". ${ }^{10}$

Di luar dua ketentuan di atas juga terdapat ketentuan lain yang dapat digunakan untuk menjerat pelaku euthanasia, yaitu ketentuan Pasal 356 (3) KUHP

${ }^{10}$ Hermien Hardiati Koeswadji, Hukum Kedokteran. Studi tentang Hubungan Hukum dalam Mana Dokter sebagai Salah Satu Pihak, (Jakarta: PT. Aditya Bakti, 1998. 
yang juga mengancam terhadap "Penganiayaan yang dilakukan dengan memberikan bahan yang berbahaya bagi nyawa dan kesehatan untuk dimakan atau diminum". Selain itu patut juga diperhatikan adanya ketentuan dalam Bab XV KUHP khususnya Pasal 304 dan Pasal 306 (2). ${ }^{11}$ Dalam ketentuan Pasal 304 KUHP dinyatakan, "Barang siapa dengan sengaja menempatkan atau membiarkan seorang dalam keadaan sengsara, padahal menurut hukum yang berlaku baginya atau karena persetujuan, dia wajib memberikan kehidupan, perawatan atau pemeliharaan kepada orang itu, diancam dengan pidana penjara paling lama dua tahun delapan bulan atau denda paling banyak tiga ratus rupiah".

Sementara dalam ketentuan Pasal 306 (2) KUHP dinyatakan, "Jika mengakibatkan kematian, perbuatan tersebut dikenakan pidana penjara maksimal sembilan tahun". Dua ketentuan terakhir tersebut di atas memberikan penegasan, bahwa dalam konteks hukum positif di Indonesia, meninggalkan orang yang perlu ditolong juga dikualifikasi sebagai tindak pidana. Dua pasal terakhir ini juga bermakna melarang terjadinya euthanasia pasif yang sering terjadi di Indonesia.

\section{Pelaksanaan Euthanasia di Negara yang menganut sistem hukum Anglo Saxon}

Euthanasia agresif dinyatakan ilegal di banyak negara bagian di Amerika, bahkan perbuatan euhanasia merupakan perbuatan yang melanggar hukum, Akan tetapi ada negara bagian di Amerika yang hukumannya secara eksplisit mengizinkan pasien terminal (pasien yang tidak mungkin lagi disembuhkan) mengakhiri hidupnya adalah negara bagian Oregon, yang pada tahun 1997 melegalisasikan kemungkinan di lakukannya euthanasia dengan memberlakukan Undang-undang tentang kematian yang pantas. ${ }^{12}$

Dalam Undang-undang ini ada beberapa kelemahan, Undang-undang Euthanasia ini hanya menyangkut bunuh diri berbantuan, bukan euthanasia. Syarat-syarat yang diwajibkan cukup ketat dimana pasien terminal berusia 18 tahun keatas boleh meminta bantuan untuk bunuh diri jika mereka diperkirakan akan meninggal dalam enam bulan dan keinginan ini harus diajukan sampai

${ }^{11}$ Djoko Prakoso dan Djaman Andhi Nirwanto, Euthanasia Hak Azasi Manusia, Manusia Dan Hukum, Medan: Pustaka Bangsa Press, 1984.

12 Lihat Oregon Death with dignity act) ( Robin Lunge, Maria Royle, Micheil Slater. http:// www.leg.state.vt.us/ report/05death/death_with dignity_report. Htm. Diakses 24 Januari 2011) 
Syarat-syarat yang diwajibkan cukup ketat, dimana pasien terminal berusia 18 tahun keatas boleh minta bantuan untuk bunuh diri, jika mereka diperkirakan akan meninggal dalam 6 bulan dan keinginan ini harus diajukan sampai 3 kali pasien, dimana 2 kali secara lisan (dengan tenggang waktu 15 hari diantaranya) dan sekali secara tertulis (dihadiri 2 saksi dimana salah satu saksi tidak boleh memiliki hubungan keluarga dengan pasien). Dokter kedua harus mengkonfirmasikan diagnosa penyakit dan prognosis serta memastikan pasien dalam mengambil keputusan itu tidak berada dalam gangguan mental.

Hukum juga harus mengatur secara tegas bahwa keputusan pasien untuk mengakhiri hidup tidak boleh berpengaruh terhadap asuransi yang dimilikinya baik asuransi kesehatan, jiwa maupun kecelakaan ataupun simpanan hari tuanya.nSetelah memenuhi persyaratan diatas pasien berhak untuk resep obat untu mengakhiri hidup. Undang-undang tidak mengizinkan dokter atau orang lain untuk mengakhiri hidup pasien dengan suntikan mematikan atau euthanasian aktif, artinya undang-undang memberikan wewenang dokter untuk memberikan resep mematikan namun secara tegas menolak euthanasia aktif. ${ }^{13}$

Kasus menarik di Amerika tentang euthanasia adalah terri Schiovo meninggal dunia di negara bagian Florida, 31 Maret 2005 atau 13 hari setelah Mahkamah Agung Amerika memberikan izin mencabut pipa makan yang selama ini memungkinkan pasien dalam keadaan koma ini masih bisa tetap hidup. Komanya mulai pada thun 1990 saat Terri jatuh dari rumahnya dan ditemukan oleh suaminya, Michel Siavo, dalam keadaan gagal jantung. Setelah ambulans tim medis langsung dipanggil Terri dapat diresusitasi lagi tapi karena karena cukup lama tidak bernafas ia mengalami kerusakan otak yang cukup berat akibat kekurangan oksigen. Menurut keterangan Medis gagal jantung ini diakibatkan oleh ketidakseimbangan potasium, dalam tubuhnya. Oleh karena itu dokternya kemudian dituduh malpraktek dan harus membayar ganti rugi cukup besar karena dinilai lalai dan tidak menemukan kondisi yang membahayakan ini pada pasiennya.

Setelah Terri Schavo Slama 8 tahun berada dalam keadaan koma, Maka pada bulan Mei 1988 suaminya yang bernama Michel Sheavo mengajukan permohonan ke Pengadilan agar pipa alat bantu makan pada istrinya bisa dicabut agar istrinya bisa meninggal dengan tenang. Namun orang tua Terri schiavo yaitu

13 Lihat (Robin luange, Maria Royle, Micheil Sleter, http:// www/leg.state.vt.us/report/05death-with-dignity-report, htm diakses 24 januari 2011). 
robert dan Merri Schindler menyatakan keberatan dan menempuh jalur hukum guna menetang niat menantu mereka tersebut. Dua kali pipa alat bantu Terri dilepas dengan izin pengadiln tetapi sesudah itu, beberapa hari harus dipasang kembali atas perintah hakim yang lebih tinggi. Pada tahun 2001 Hakim pengadilan memutuskan bahwa bukti yang jelas dan meyakinkan bahwa Terri Schiovo akan memilih untuk tidak menerima pengobatan yang memperbanjang hidup dalam keadaan yang kemudian di terapkan. Keputusan ini juga di terapkan oleh Pengadilan Banding Florida dan membantah mendengarkan oleh Mahkamah Agung Florida. Ketika tabung pengisi Terri schiavo telah dihapus untuk kedua kalinya pada tahun 2003, badan legislatif Florida diciptakan “Terri Law" untuk mengesampingkan putusan pengadilan, dan tabung pipa makanan tersebut kembali dimasukkan. Hukum ini kemudian memutuskan pelanggaran konstitusional pemisahan kekuasaan. ${ }^{14}$

Akhirnya hakim memutuskan bahwa pipa makanan boleh dilepaskan, maka para pendukung keluarga Schilder melakukan upaya-upaya guna menggerakkan senat Amerika agar membuat Undang-undang yang memerintahkan pengadilan federal untuk meninjau kembali putusan Hakim tersebut. Undang-undang ini langsung didukung oleh Dewan Pengadilan Amerika serikat dan ditandatangani oleh Dewan perwakilan Amerika Serikat dan dindatangani oleh Presiden George Walker Bush. Tetapi berdasarkan kekuasaan Hukum di Amerika kekuasaan kehakiman adalah independen, yang pada akhirnya ternyata Hakim Federal membenarkan putusan Hakim terdahulu. Kejadian tersebut telah memberikan penegasan bahwa tindakan euthanasia tidak dilegalkan di Amerika.

\section{PENUTUP}

Negara yang menganut sistem hukum Eropa Kontinental yaitu Indonesia dan Belanda terdapat dualisme pemberlakuan euthanasia dimana Indonesia tidak melegalkan penerapan euthanasia, hal ini termuat dalam ketentuan pasal 344 KUHP, sedangkan pada Belanda yang menganut sistem hukum yang sama, secara tegas melegalkan penerapan euthanasia. Ketentuan ini dimuat dalam code penal section 40 dan pasal 293 KUHP Belanda. Berbeda halnya dengan negara yang menganut sistem hukumAnglo saxon seperti Amerika melarang keras adanya

${ }^{14}$ ( TimothyQuil, http:// www.nejm.org/doi/full/10.1005/Nejmp058062, diakses 2 Januari 
euthanasia, hal ini didasarkan adanya putusan pengadilan di Amerika yang menolak penerapan euthanasia sebagai sebuah yurisprudensi yang diberlakukan secara turun temurun oleh masyarakat Amerika. Maka dapat disimpulkan Bahwa Pada Negara yang menganut Sistem Hukum Eropa Kontinental yang menggunakann sistem hukum tetulis seperti Belanda, dan Indonesia, Melegakalkan. Sedangkan Pada Negara yang menganut sisttem Hukum anglo Saxson, Tidak Melegalkan Pemberlakuan Euthanasia.

Pemerintah harus membuat regulasi ethanasia yang berbasis HAM, atau Memasukkan ethanasia dalam ketentuan Undang-Undang kesehatan dan Undangundang Praktek Kedokteran untuk memperjelas Euthanasia mana yang di larang dan diperbolehan untuk membantu penegak Hukum. Apabila hukum di negara yang menganut anglo saxon dan eropa kontinental telah melegalkan adanya eutanasia, semoga tetap memperhatikan dan mempertimbangkan sisi-sisi nilainilainya baik sosial, etika, maupun moral terutama Agama. 


\section{DAFTAR PUSTAKA}

Abu Zahrah, Muhammad,. 2005. Al jarimah Wal Uqubah fil Fiqhil-islamiy, Kairo: Maktabah Al Angelo, al-Mishriyah

Andi Zainal Abidin Farid. 2007. Hukum Pidana 1, Jakarta: Sinar Grafika

Ari Yunanto dan Helmi. 2010. Hukum Pidana Malpraktik Medik, Yogyakarta: C.V Andi Offset

Aris Wibudi. 2002. Euthanasia. Bogor: ITB

Djoko Prakoso dan Djaman Andhi Nirwanto. 1984. Euthanasia Hak Azasi Manusia, Manusia Dan Hukum. Medan: Pustaka Bangsa Press

Endang Kusuma Astuti. 2003. Tanggungjawab Hukum Dokter dalam Upaya Pelayanan Medis Kepada Pasien: Aneka Wacama tentang Hukum, Yogyakarta: Kanisius

Halimi , Imron. 1990. Euthanasia. Solo: Ramadhani

Hazewinkel Suringa. 1993. Unsur Peniadaan Pidana Dalam Sistem Pemidanaan Di Indonesia. Bandung: Refika Aditama

Hermien Hardiati Koeswadji. 1998. Hukum Kedokteran. Studi tentang Hubungan Hukum dalam Mana Dokter sebagai Salah Satu Pihak, (Jakarta: PT. Aditya Bakti

J.Guwandi. 2005. Hukum Medik (Medical Law), Jakarta: Balai Penerbit FKUI

J.E. Sahetapi. 1976. Euthanasia Dan Jenis-Jenisnya, Jakarta: Badan Pembinaan Hukum Nasional

M. Jusuf Hanafiah dan Amri Amir. 1997. Etika Kedokteran Dan Hukum Kesehatan, Jakarta: EGC

M. Karjadi. 1975. Himpunan Undang-Undang Terpenting Di Indonesia, Bogor: Politea

Moeljatno. 2005. Kitab Undang-Undang Hukum Pidana, Jakarta: PT. Rineka Cipta 1982. Asas-Asas Hukum Pidana, Jakarta: PT. Rineka Cipta

R. Soerarjo Darsono. 1989. Euthanasia Dalam Praktik, Jakarta: EGC

Ramali, Ahmad. 1986. Kamus Kedokteran, Jakarta: Jambatan

Wirjono Prodjodikoro. 1977. Asas-Asas Hukum Pidana Di Indonesia, Jakarta: Refika Aditama

Undang - Undang No.36 tahun 2009 tentang kesehatan

Undang - Undang No.29 tahun 2004 tentang praktik kedokteran 